УДК 341.1/.8:340.134:328.185:061.1€С

DOI https: / / doi.org/10.32837/yuv.v0i1.1579

\author{
О. Макаренков, \\ кандидат юридичних наук, доцент, \\ доцент кафедри історії і теорії держави та права, \\ заступник декана з міжнародної діяльності юридичного факультету \\ Запорізького національного університету
}

\title{
КОМПОНЕНТИ СТРУКТУРИ ГЛОБАЛІЗАЦІЙНИХ ТРЕНДІВ АНТИКОРУПЦИЙНИХ ПЕРЕТВОРЕНЬ ПУБЛІЧНОГО ПРАВА У ВІДКРИТОМУ СУСПІЛЬСТВІ
}

Осмислення феномену глобалізації вбачається можливим за допомогою методологічного інструментарію теоріі та філософії (до поч. XX ст. - енциклопедіï) права, оскільки онтологічний масштаб глобалізації і права співвідносяться як частина й ціле, а правового виміру глобалізації та права - як рівнозначні системи конструктів світогляду людства. У юридичній науці глобалізація потребує перегляду багатьох усталених теоретичних конструкцій. Однак власне теорія як найвища форма розуміння і відображення правової реальності виникає набагато пізніше. Будь-яка теорія як система понять, суджень, концепцій набуває статусу науки тільки тоді, коли піднімається до усвідомлення сутності явищ і закономірностей їхнього буття [1, с. 118]. Пізнання юридичної науки концентрується на природі людини та створеного нею права. Отримання й застосування достовірних знань про ці явища $є$ способом забезпечення стійкого поступу духовності людей - єдиної прийнятної основи елімінації корупційних інтенцій, практик із правових відносин. Цей спосіб універсально ефективний для попередження корупції в усіх країнах.

Мета статті - розкрити компоненти структури глобалізаційних трендів антикорупційних перетворень публічного права у відкритому суспільстві.

Відображення порушеної проблематики у правовій доктрині зустрічаємо у численних працях О.M. Братусєвої, де розкрито правові культури в умовах глобалізації, А.В. Бухарєва - теоретико-правові аспекти організаційно-управлінської діяльності із профілактики корупції в районних судах РФ; С.Ю. Зайцева - моделі взаємодії транснаціональних корпорацій і сучасної держави; М.М. Марченка - тенденціï розвитку Європейського Союзу та його правової системи, Ю.М. Оборотова - загальнотеоретичні аспекти традицій і новацій у правовому розвитку, О.О. Сидоренко - сучасні тенденціі розвитку правової системи України в умовах глобалізації, І.В. Яковюк правові основи європейської інтеграції та їі вплив на державно-правовий розвиток України, В.В. Янкова - теоретико-методологічний аналіз глобалізації у сфері публічного права; В.А. Суханова - міжнародне співробітництво в боротьбі з корупцією в органах влади.

Сучасне поглиблення глобальних проблем супроводжується тенденцією посилення конвергенції правових стандартів різних націй, під час якого виникають можливості віднайти нові рішення для усталеного соціального прогресу, й елімінації перешкод для нього. Йдеться про стирання відмінностей між міжнародним і національним правом, приватним і публічним, м'яким і жорстким. Сучасні тенденції розвитку права роблять вельми проблематичним протиставлення в рамках західної правової традиції двох правових сімей - англосаксонської (загального 
права) і романо-германської (континентальної). Інтеграційні процеси ведуть до їх поступової конвергенції [1, с. 406, 411]. Природно-правовий підхід орієнтує на необхідність врахування властивих людині від моменту народження якостей, які потрібно розвивати, зокрема через мережу інститутів соціалізації та за допомогою законодавчих норм. Організаційно-правова система стимулювання людських чеснот зумовлює формування психологічно сильних громадян. Їхні спільноти становлять ядро нації та міць держави, мультиплікаційний ефект від соціальної активності яких оздоровлює відносини усього населення та на міжнаціональному рівні, де юридично розвинена комунікація народів (націй) означає спершу стагнацію (лат. stagno - роблю нерухомим, зупиняю; stagnum - стояча вода), а потім вирішення проблем, які торкаються усіх на Землі. Вчені відзначають, зокрема, що подолання корупції має психологічний аспект, адже посадову особу, котра характеризується низьким рівнем правової свідомості (правовим нігілізмом), відсутністю чіткої ідеології державної служби, ігноруванням моральних принципів, легше схилити до вчинення корупційних діянь [2, с. 17].

Слово «тренд» використовується в українській мові внаслідок транскрибування англійського слова «trend», яким позначаємо тенденцію як явище. Тенденція (тренд, мейнстрім) є змінами, перетвореннями когось чи чогось, зумовленими природою міжнаціональних, глобальних комунікацій і взаємодії змін в антикорупційних трансформаціях публічного права. Ті з них, які суттєво впливають на правові механізми протидії корупції, номінуємо словами «головний», «основний» тощо. Мегатрендом вважається основний напрямок рухів, що визначають обличчя і суть нашого суспільства [3, с. 9], у т. ч. у межах порушеної нами проблеми.

Корупційні відносини виникають завжди, коли люди на публічній посаді керуються приватним інтересом всупереч інтересу публічному. Із визна- чень поняття корупції виявляється, що це прагнення наживи, споживання, отримання матеріального, а не духовно-культурного розвитку. Відповідно, тенденцією вважаємо посилення роботи урядів у напрямі застосування суворіших заходів для забезпечення виконання вимог законодавства / нормативно-правових актів, якщо чинна тактика виявляється неефективним інструментом врегулювання дефіциту матеріальних та інших ресурсів. Однією 3 ключових характеристик, типових для провідних урядів у майбутньому, стає нормативно-правова база, продумана, необхідна, достатня і здатна задовольняти потреби людей [4, с. 44, 60]. Це важливо й для України, публічна влада якої повинна сприяти побудові миролюбного та відкритого суспільства в інтересах сталого розвитку, забезпечення доступу до правосуддя для всіх i створення ефективних, підзвітних і заснованих на широкій участі інституцій на всіх рівнях (пп. 16 п. 2) [5]. У судовій і правоохоронній сферах підсилюються вимоги до незалежності, етики та інших параметрів доброчесності під час протидії корупції, збільшується кількість органів із розслідування корупційних злочинів і відшкодування завданих країні збитків. Активізується робота $з$ повернення грошей, які за межами власної країни були накопичені корупціонерами на банківських рахунках, вкладені у нерухомість чи інші цінні активи. Це напрям досудового розслідування, що став одним із головних для Інтерполу та Європолу.

Як міжурядова організація 194 країн-членів Інтерпол уособлює глобальні зусилля націй чіз перетворення світу на більш безпечний, який викорінює далекосяжні наслідки корупції, що підривають політичну, соціальну й економічну стабільність і загрожують безпеці суспільства загалом. Зокрема, корупція створює благодатний грунт для організованої злочинної діяльності, навіть тероризму, оскільки злочинці допомагають у своїй протизаконній діяльності співучастю корумпованих держав- 
них чиновників. За підсумками 86-і сесії Генеральної Асамблеї Інтерполу 26-29 вересня 2017 р. (м. Пекін) серед основних цілей правоохоронної діяльності та складників глобальної безпеки було визначено сприяння глобальній доброчесності («global integrity») через забезпечення належного управління та верховенства права; підвищення кваліфікації слідчих, експертів та інших осіб, котрі залучаються до розслідування корупційних злочинів; сприяння культурі доброчесності та нетерпимості до корупції; побудову механізмів підтримки та захисту доброчесності та відновлення викрадених активів [6].

Суттєві перетворення механізмів утвердження людських чеснот відбуваються у сфері публічно-правових відносин правовими засобами, які впродовж конкретного часу домінують над будь-якими іншими трансформаціями та підпорядковують їх, поширюючись на усі нації світу або ту їхню частину, екзистенція якої детермінує життя усіх інших націй. Сьогодні абсолютна більшість теоретичних досліджень і їхніх практичних імплементацій інтерпретує корупцію як економічне явище, а тому ii вимірюють економічно, забороняють і карають за неправомірні матеріальні вигоди, отримані прямо і / або опосередковано внаслідок підміни публічного інтересу приватним інтересом чиновника органів публічної влади (його близьких осіб). Водночас проблема корупції глобально не вирішується, більш того, створюється обгрунтування такої неможливості за нинішніх умов розвитку людства, де акцент так само зроблено на економіці. Неспроможність такого пояснення демонструють проблеми, з якими сучасний світ живе, наприклад, пандемію класу короновірусів (від лат. coronaviridae) COVID19 із 2020 р. На додаток до обов'язкового опосередкованих корупцією війн (в Афганістані, Іраку, Сиріі, Грузіі, Україні, Лівї та в деяких інших країнах Африки), терористичних актів, торгівлі людьми з метою сексуального і / або трудового рабства [7, с. 13]; незаконній торгівлі зброєю, наркотиками та людськими органами (тканинами), феномену біженців, людська цивілізація XXI ст. отримала ще й проблему епідеміологічного характеру. Сукупно усе це економічно викликало влучно номіновану Міжнародним Валютним Фондом тенденцію безпрецедентної невизначеності щодо економічних і фінансових перспектив і необхідності зосередити політичні пріоритети на короткостроковому стримуванні та стабілізації, що може забезпечити підтримку платіжного балансу для посилення реакції публічної влади, щоб, коли ситуація відновиться, фокус знову міг зміститися на рішення проблем довгострокових структурних реформ задля більш сильного й інклюзивного, стійкого зростання.

Однак питання про невизначеність відносна. Норми як національного, так і міжнародного права абсолютно чітко визначені. Відповідна якість характерна і для фінансів, на відміну від економіки, де визначеність закінчується вірогідностями варіантів поведінки акторів економічних відносин. Виходить, що, якщо усі діяли за законом (міжнародними домовленостями), то невизначеність, а тим більш критична для виживання людства концентрація глобальних проблем, настати не могла а-пріорі. А оскільки нині усе людство, а не тільки окремі нації чи декілька націй опинилися у ще більш критичній ситуації, ніж рік тому, то це означає, що юридичні умови розвитку людства не дотримуються, адже природне право не відображено у законодавчих актах і / або правові акти не реалізуються у реальному житті. I якщо право, будучи гармонійним, збалансованим, людиновимірним за визначенням, не стає нормою поведінки людей, то ми маємо справу з вадами людської природи, які у реальному соціальному житті не узгоджені з онтологічно досконалою матерією права. Саме ці вади - причина відсутності кореляції права й людських чеснот. А їі стійкість - передумова експоненти 
розвитку людини та суспільства - іï стійкість, а не нарощування та поглиблення глобальних проблем, як нині.

Поелементний аналіз глобальних тенденцій перетворень норм публічного права дозволяє встановити дисфункцію, яка виключала подолання корупції та запуск у дію усього набору людських чеснот під час перебігу правових відносин. За суб'єктним складом інтерес становлять ті люди (їхні організації), котрі своїми діяннями справляли визначальний вплив на зміст і peaлізацію ухвалених рішень. До таких суб'єктів належать насамперед чиновники, які отримали мандат довіри від народу, - президенти та парламентарії країн, мери та члени місцевих рад депутатів, а також відповідно до чинного законодавства обрані судді, прокурори, керівники поліції та ін. Фахівці 3 теорії права, політичних і правових вчень обгрунтували найвищу соціальну владу цих осіб як таку, що легітимізована безпосередньо самими людьми. У реальному житті правова доктрина викривляється потраплянням на ці посади підприємців, тобто людей, які за своїми талантами повинні займатися господарюванням і примноженням прибутків, a не управлінням задля задоволення публічних інтересів. Їх номінують олігархами, й вони - організаційно-правова першопричина дисфункції права, корупції та, як наслідок, зростання глобальних проблем. Контрзаходи щодо таких підприємців (чиновників) законодавчо визначені та імплементовані у соціальну практику зобов'язання із корпоративної соціальної відповідальності, а саме: поваги до суверенітету i конституційного ладу держави, де здійснюється господарська діяльність; дотримання особистих, соціально-економічних, громадянських прав людини та колективних прав; утримання від корупційних практик, дотримання законодавства у сферах податків й економічної конкуренції, а також утримання від зловживання своєю економічною владою для погіршення добробуту країн, у якій вони діють [8, с. 145].
Інтродукція корупціонерів до управлінських / силових структур на міжнародному рівні, у т. ч. через корупційні впливи транснаціональних корпорацій, нівелює сенс міжнародного права. Тоді отримуємо, як влучно наголосили І.Б. Іванків і М.I. Козюбра, ситуації, за яких право на здорове довкілля порушується, адже механізми контролю за шкідливим виробництвом слабкі або зруйновані корупційними зв'язками; право на сталий розвиток порушується, оскільки правлячі еліти держав чи регіонів вдаються до корупції, порушуючи у такий спосіб можливості народів на розвиток [9, с. 173-174]. Користь від глобалізації дуже часто була набагато меншою, ніж стверджували іiі захисники, а іiі ціна - набагато вищою, оскільки руйнувалися усталений життєздатний побут і система господарських відносин, у політичні процеси широко проникала коррупція, i, крім того, швидкі зміни не давали країнам часу для культурної адаптації. За економічними (фінансовими, банківськими тощо) кризами йшли масове безробіття та зубожіння населення, що спричиняли більш довгострокові проблеми розпаду соціальних структур - від актів насильства в Латинській Америці до етнічних конфліктів в інших частинах світу, наприклад, в Індонезії [10, с. 11].

Не менш важливою складовою частиною глобалізаційних трендів антикорупційних перетворень норм публічного права стає також суб'єктивна сторона чиновників найвищих рівнів органів публічної влади, у т. ч. на міжнародному рівні, та підприємців, авторів масштабних господарських процесів. Правосвідомість, воля до права, правові почуття й емоції, асоціації та переживання, інші складники психічного життя цих людей демонструють справжність їніх намірів щодо втілення правової доктрини у практиці суспільних відносин. Забезпеченість прав людини та суспільства, їхній розвиток на тлі низхідного тренду глобальних проблем символізують, що усвідомлене право досягає вершин свого 
культурного вираження через появу такої якості, як душевність [11, с. 345] та інших високих людських чеснот, що постійно розвиваються, і чим більше у них глибини, тим вони продуктивніші для людства. Специфіка правової реальності виявляється в тому, що вона утворює своєрідну «картину світу», тобто творить дійсний образ права, який побутує в індивідуальній і колективній правосвідомості [12, с. 312].

Щира спрямованість суб'єктів публічно-правових відносин на досягнення актуальних для людей цілей $€$ ще одним елементом досліджуваних у цій роботі тенденцій. Матеріальні та духовні блага як результати таких цілей - предмети соціального світу, що становлять основу об'єкта правових відносин. Відсутність корупції у цих зв'язках, окрім актуальності, передбачає однакову всім рівність (Г.С. Сковорода), раціональність, максимальне спрямування часу та інших ресурсів на розвиток, а не тільки на споживання, тим більш сумнівної якості продуктів культури. Визначення таких предметів повинно бути для задоволення інтересів кожного й усіх. Це складний процес, заснований виключно на доброчесності як вияві необхідного набору людських чеснот, проте їхні відхилення та викривлення не вичерпуються наявним нормативним поняттям «корупція», адже вимагають свого уточнення, щоб адекватно відображати недоброчесні викривлення публічно-правових відносин, охоплювати їх своїм змістом. Крім цього, корупційні правопорушення тісно пов'язані 3 відмивання грошей, отриманих злочинним шляхом, і низкою інших злочинів, зазвичай цілих злочинних організацій. Об'єктивна сторона виявляється у діяннях (дії, бездіяльності), іхній змістовій наповненості, достатності задля досягнення поставлених цілей повсюдного максимального забезпечення прав людини та соціуму. Успішність сукупної дії усіх вищезазначених елементів зумовлюється у підсумку їхньою відповідністю історичним, цивілізаційним, культур- ним та іншим соціальним умовам, за яких вони реалізуються.

Отже, глобалізація і право, у т. ч. й публічні антикорупційні законодавство і практика його застосування, явища соціальні, динамічні, мінливі, історичні та цивілізаційні. Негідне людини й тварини насильство XX ст. (рівно як i попередніх століть), що вчинялося за формальними зовнішніми (фенотипом) ознаками людьми, після Першої та Другої світових воєн проілюструвало юристам, а ще більше політикам i підприємцям, існування й необхідність неухильного дотримання загальних для усіх людей цінностей. Відбувалося розуміння глобальності правових цінностей i людських чеснот, взаємозалежності людей один від одного. Хоча внаслідок такого перетворення доведених у правовій доктрині (В.M. Корецьким, Г. Лаутерпахтом, Р. Лемкіним, П.О. Недбайлом та ін.) аксіом гуманітарного змісту вищезазначений тип насильства тільки поменшав, а точніше змістився у регіони, що виявилася економічно, військового, духовно нездатними його попередити та йому протистояти. Ця тенденція творення насильства істотами людської подоби наслідок тенденції збереження потурання людським вадам, зневажання права та інших відхилень від правових цінностей, а особливо у публічних правових внутрішньонаціональних і міжнародних відносинах. Переслідування приватного інтересу за рахунок публічного виявляє у цих відносинах - тренд глобальної корупції, а саме: одні країни багатіють за рахунок інших, а не відповідно до принципів права; розвиток інвестиційних проектів, особливо масштабних, складних технологічно й дороговартісних (наприклад, у сфері авіабудування, автомобілебудування, енергетики тощо), одних країн в інших країнах часто відбувається внаслідок підкупів (хабарів) найвищих посадових осіб (членів королівських родин, президентів, членів урядів, парламентаріїв), а не відповідно до правових принципів чесної економічної конкуренції; насиль- 
ство домінує над заохоченням і стимулами там, де це абсолютно невиправдано правовою доктриною; рабство (у т. ч. із сексуальною метою), викрадення людей для отримання викупу чи для використання їхніх органів (тканин), гвалтування, каліцтва, вбивства під час військових операцій та інші акти насильства, що нижчі за гідність тварини, у XXI ст. далеко непоодинокі, а глобальні, особливо щодо біженців. Корупція - наслідок і причина інших соціальних неправових відхилень людей, які разом тільки посилюють відчуття залежності, вразливості та інших детермінацій одних націй від рішень (діянь) інших націй. Міжнаціональні кореляції ідентифікують глобальність і відповідальність, а не відособленість i сваволю. Водночас корупційність та інші наслідки проявів людських вад детермінують тенденцію посилення глобальних проблем. Їхньою особливістю стає не глобальний, а виключно глокальний генезис, тобто, переслідуючи вигоду власної нації, глобальну проблему створює і / або визначальним чином посилює одна чи до десяти націй на Землі, що, звісно, не вичерпує людство і не є соціальною глобальністю, а ось негативні наслідки внаслідок такої деструктивної активності виникають для усіх націй нашої планети. Відповідно, вирішення глобальних проблем (війн, екологічних, економічної і / або духовної злиденності тощо) передбачає 3-поміж іншого виключення корупції, що дозволяє одним націям переслідувати свої національні інтереси всупереч інтересам публічним - глобальним, всього людства. Правове забезпечення стійкості кореляції публічних інтересів людства 3 діяннями (рішеннями) кожної нації - єдиний спосіб створити тенденцію соціального розвитку у глобальному масштабі, а не для вузького кола осіб, залишаючись перманентно відкритим до практичного впровадження найкращих, із позиції прогресу на підставі правових цінностей, пропозицій.

Тренди в антикорупційних трансформаціях публічного права станов- лять усі суттєві перетворення механізмів утвердження людських чеснот у сфері публічно-правових відносин правовими засобами, які впродовж конкретного часу домінують над будьякими іншими трансформаціями та підпорядковують ї. Глобальним вони стають, оскільки стосуються громадян усіх націй. Глобальність таких трендів в основі зумовлена однаковою природою людини та змістом норм права, потрібних для розвитку ії чеснот (духовності) упродовж усього життя. Якщо корупція долається в межах однієї країни чи їхньої групи, то ефект від неї в інших країнах негативно впливає на всіх, обмежуючи людські можливості та сповільнюючи соціальний прогрес. За сферами життєдіяльності глобальні тренди недоброчесності вражають економічні, правоохоронні та інші правові відносини, що повинно бути враховано у законодавчих механізмах розвитку відкритого прогресу суспільства. В Україні такі тенденції продовжують актуалізуватися в межах регіональних питань інтеграції до структур ЄС. На рівні доктрини урахування трендів відображається у змінах парадигми правових досліджень, зокрема із проблем протидії корупції.

Серед ключових елементів глобалізаційних тенденцій антикорупційних перетворень норм публічного права виокремлюємо суб'єктів, суб'єктивну сторону (наміри, мотиви та інші елементи психічного ставлення людини), об'єкт та об'єктивну сторону, а також конкретно історичні, цивілізаційні, культурні та інші соціально детерміновані характеристики життєвих обставин. Специфічними для них усіх у контексті порушеної проблематики людські чесноти стають не меншою мірою, ніж соціально детерміновані вади людської природи. Будучи іманентними рисами людини, іï чесноти домінують і задають тенденцію у правових чи інших юридично потенційно значущих (наприклад, інтимних тощо) відносинах тільки тоді, коли щонайменше наявні достатні для цього зазвичай свідомі й обов'яз- 
ково вольові зусилля кожного. Діяння доброчесної людини отримують підтримку політично, а інколи й економічно, енергетично переважаючої частини соціуму. Тільки за таких умов зазначені перетворення стають органічними та стійкими.

У статті досліджено компоненти структури глобалізаційних трендів антикорупиійних перетворень публічного права у відкритому суспільстві. Визначено, що глобалізація $і$ право (зокрема публічні антикорупиійні законодавство $і$ практика його застосування) явища соиіальні, динамічні, мінливі, історичні й иивілізаційні. Негідне людини та тварини насильство XX cm. проілюструвало необхідність неухильного дотримання загальних для усіх людей иінностей, які стосуються кожного й усіх одразу, у будь-якому місиі на Землі та будь-коли. Відбувалося розуміння глобальності правових иінностей $i$ людських чеснот, взаємозалежності людей один від одного. Хоча внаслідок такого перетворення доведених у правовій доктрині аксіом гуманітарного змісту, вищезазначений тип насильства тільки поменшав, a точніше, змістився у регіони, що виявилися економічно, військово, духовно нездатними його попередити та йому протистояти. Ця тендениія творення насильства наслідок тенденції потурання людським вадам, зневажання права у публічних правових національних $i$ міжнародних відносинах. Визначено, щзо тренди в антикорупційних трансформаціях публічного права становлять усі суттєві перетворення механізмів утвердження людських чеснот у сфері публічно-правових відносин правовими засобами, які впродовж конкретного часу домінують над будь-якими іншими трансформаціями та підпорядковують ї. Глобальним вони стають, оскільки стосуються громадян усіх націй.
Підсумовано, що серед ключових елементів глобалізаційних тенденцій антикорупиійних перетворень норм публічного права наявні суб'єкт, суб'єктивна сторона (наміри, мотиви та інші елементи психічного ставлення людини), об’єкт та об'єктивна сторона, а також конкретно історичні, цивілізаційні, культурні та інші соціально детерміновані характеристики життєвих обставин. Специфічними для них усіх у контексті порушеної проблематики людські чесноти стають не меншою мірою, ніж соціально детерміновані вади людської природи.

Ключові слова: глобалізація, доброчесність, Європейський Союз, корупція, право, правосвідомість, рівноправність, тренд.

Makarenkov O. Components of the structure anti-corruption transformations of public law globalization trends in an open society

The article reveals components of the globalization trends structure of anti-corruption transformations of public law in an open society. It is determined that globalization and law (in particular, public anticorruption legislation and practice of its application), social, dynamic, changing, historical and civilizational phenomena. Unworthy human and animal violence of the twentieth century illustrated the need to adhere to the common values of all people, which apply to each and everyone at once, anywhere on Earth and at any time. There was an understanding of the globality of legal values and human virtues, the interdependence of people from each other. Although as a result of such a transformation of the axioms of humanitarian content proved in legal doctrine, the above-mentioned type of violence only decreased, or rather shifted to regions that were economically, militarily, spiritually unable to prevent and resist it. And 
this tendency to create violence is a consequence of the tendency to indulge in human defects, contempt for the law in public legal national and international relations.

It is determined that trends in anticorruption transformations of public law are all significant changes in the mechanisms of affirmation of human virtues in the field of public relations by legal means, which over time dominate over any other transformations and subordinate them. They become global insofar as they affect citizens of all nations. They become global insofar as they affect citizens of all nations. If corruption is tackled within one country or group of people, its effects in other countries negatively affect everyone, limiting human capacity and slowing down social progress. In terms of life, global trends of dishonesty affect economic, law enforcement and other legal relations, which should be taken into account in the legislative mechanisms for the development of a society open to progress. In Ukraine, the following trends are currently still actualizing within regional issues of integration into $E U$ structures.

It is concluded that among the key elements of the globalization trends of anti-corruption transformations of public law are the subject, the subjective side (intentions, motives and other elements of the mental attitude of man), the object and the objective side, as well as specifically historical, civilizational, cultural and other socially determined characteristics of life circumstances. Specific for all of them in the context of the issues raised, human virtues become no less than socially determined defects of human nature. Being immanent features of a person, his virtues dominate and set a trend in legal or other legally potentially significant relationships. This happens only when there is a sufficient conscious and strong-willed effort of everyone. At the same time, the actions of a virtuous person receive the support of the politically, and sometimes economically, energetically predominant part of society.

Key words: globalization, integrity, European Union, corruption, law, legal awareness, equality, trend.

\section{Література}

1. Арзамасов Ю.Г., Баранов В.М., Варламова Н.В. и др. Теория государства и права в науке, образовании, практике : монография / пред. ред. совета Т.Я. Хабриева. Москва : ИД Юриспруденции, 2016. 480 c.

2. Падалка Р.О. Верховенство права як основоположний принции права: автореф. дис. ... канд. юрид. наук : 12.00.01. Київ, 2017. 20 c.

3. Нейсбит Д. Мегатренды. Москва : ACT, 2003. 384 c.

4. Future State 2030: The global megatrends shaping governments. 2014. URL: https: / / assets.kpmg / content / dam / kpmg / pdf/2014/02 / future-state-2030-v3.pdf

5. Про Цілі сталого розвитку України на період до 2030 року. Указ Президента України № $722 / 2019$ віа 30 вересня 2019 p. URL: https: / / www.president.gov. ua/documents / 7222019-29825.

6. Our seven Global Policing Goals shape how the law enforcement community works together to create a safer world, were approved by Interpol's member countries during the 86th General Assembly session held in 2017. URL: https: / / ww.interpol.int / Who-we-are / Strategy/Global-Policing-Goals.

7. Лукач Н.М. Концептуальні засади та інституиійні механізми протидії глобальній проблемі торгівлі людьми : авторес. дис. ... канд. політ. наук: 23.00.04. Чернівиі, 2016. 20 c.

8. Pariotti E. International soft law, human right and non-state actors: toward the accountability of transnational corporations. Human Right Review. 2009. Vol. 10. P. 139-155.

9. Іванків I.Б. Права людства: стан та перспективи їх забезпечення : дис. ... канд. юрид. наук : 12.00.01. Чернівцуі, 2019. 214 с.

10. Стиглии Дж.Ю. Глобализаиия: тревожные тенденции / пер. с англ. Г.Г. Пирогова. Москва : Национальный общественно-научный фонд, 2003. 304 с.

11. Шпенглер О. Закат Европь. Очерки морфологии мировой истории. Всемирно-исторические перспективы / пер. с нем. и примеч. И.И. Маханькова. Москва: Мысль, 1998. $606 \mathrm{c}$.

12. Савенко В.В. Закон у структурі правової реальності : монографія Тернопіль : Астон, 2015. $459 \mathrm{c}$. 